\title{
Ghrelin and unacylated ghrelin stimulate human osteoblast growth via mitogen-activated protein kinase (MAPK)/phosphoinositide 3-kinase (PI3K) pathways in the absence of GHS-R1a
}

\author{
P J D Delhanty ${ }^{1}$, B C J van der Eerden ${ }^{1}, M$ van der Velde ${ }^{1}$, \\ C Gauna ${ }^{1}$, H A P Pols ${ }^{1}$, H Jahr ${ }^{1,2}$, H Chiba $^{3}$, A J van der Lely ${ }^{1}$ \\ and J P T M van Leeuwen ${ }^{1}$ \\ Departments of ${ }^{1}$ Internal Medicine and ${ }^{2}$ Orthopedics, Erasmus Medical Centre, Dr Molewaterplein 50, 3015 GD Rotterdam, The Netherlands \\ ${ }^{3}$ Department of Pathology, Sapporo Medical University School of Medicine, University of Sapporo, S-1, W-17, Sapporo 060-8556, Japan \\ (Requests for offprints should be addressed to J P T M van Leeuwen; Email: j.vanleeuwen@erasmusmc.nl)
}

\begin{abstract}
Recent studies demonstrate widespread expression of ghrelin among tissues and have uncovered its pleiotropic nature. We have examined gene expression of ghrelin and its two receptor splice variants, growth hormone secretagogue receptors (GHS-R) $1 \mathrm{a}$ and $1 \mathrm{~b}$, in human bone biopsies and in the human pre-osteoblastic SV-HFO cell line during differentiation. Additionally, we examined proliferative effects of ghrelin and unacylated ghrelin (UAG) in differentiating and non-differentiating cells. We detected GHS-R1b mRNA in human bone and osteoblasts but not ghrelin's cognate receptor GHS-R1a, using two different real-time PCR assays and both total RNA and mRNA. In osteoblasts GHS-R1b mRNA expression remained low during the first 14 days of culture, but increased $300 \%$ in differentiating cells by day 21 . Both human bone biopsies and osteoblasts expressed ghrelin mRNA, and osteoblasts were found to secrete ghrelin.
\end{abstract}

Overall, ghrelin gene expression was greater in differentiating than non-differentiating osteoblasts, but was not increased during culture in either group. Ghrelin and UAG induced thymidine uptake dose-dependently, peaking at 1 and $10 \mathrm{nM}$ respectively, at day 6 of culture in both non-differentiating and differentiating osteoblasts. The proliferative response to ghrelin and UAG declined with culture time and state of differentiation. The proliferative effects of ghrelin and UAG were suppressed by inhibitors of extracellular-signal-regulated kinase (ERK) and phosphoinositide-3 kinase, and both peptides rapidly induced ERK phosphorylation. Overall, our data suggest new roles for ghrelin and UAG in modulating human osteoblast proliferation via a novel signal transduction pathway.

Journal of Endocrinology (2006) 188, 37-47

\section{Introduction}

Ghrelin is an acylated 28-residue peptide hormone and is the natural ligand for the growth hormone $(\mathrm{GH})$ secretagogue receptor (GHS-R1a; Kojima et al. 1999, van der Lely et al. 2004, Kojima \& Kangawa 2005). The predominant form of ghrelin in serum is unacylated ghrelin (UAG). The majority of circulating ghrelin is derived from X/A-like cells in the oxyntic mucosa of the stomach with greatest expression in the fundus (Kojima et al. 1999). Ghrelin gene expression is widespread among tissues in humans, although the presence of its mRNA in human bone has not been determined (Gnanapavan $e t$ al. 2002). The GHS-R mRNA is expressed as two splice variants encoding the cognate receptor GHS-R $1 \mathrm{a}$ and the apparently non-functional receptor GHS-R1b (Howard et al. 1996). GHS-R1a signals via inositol trisphosphate generation and $\mathrm{Ca}^{2+}$ release and has constitutive activity (Howard et al. 1996, Holst et al. 2003). GHS-R1b mRNA is as widely expressed as ghrelin, whereas GHS-R1a gene expression is limited to the pituitary and a few other peripheral tissues (Guan et al. 1997, Gnanapavan et al. 2002). Ghrelin stimulates the release of growth hormone, as well as prolactin and corticotrophin (ACTH) from the anterior pituitary. However, much recent evidence suggests numerous other functions for ghrelin at the periphery, including effects on cell proliferation (Murata et al. 2002, Baldanzi et al. 2002, Broglio et al. 2002, Andreis et al. 2003, Jeffery et al. 2003, Kim et al. 2004, Nanzer et al. 2004, Zhang et al. 2004). Interestingly, although only the acylated form of ghrelin activates the GHS-R1a receptor, recent evidence suggests that UAG may also modulate cellular function and body growth, presumably by acting through an alternative receptor. For example, 
transgenic mice that overexpress UAG are smaller than their wild-type counterparts (Ariyasu et al. 2004), direct treatment with UAG alters adipogenesis in the bone marrow of rats (Thompson et al. 2003), and in vitro UAG inhibits apoptosis of human cardiomyocytes and endothelial cells (Baldanzi et al. 2002). To the best of our knowledge nothing has been reported on the proliferative effects of UAG in osteoblasts.

In vivo, ghrelin may have an indirect effect on bone through its stimulation of $\mathrm{GH}$ release. However, the GHS-R1a agonist hexarelin inhibits markers of bone resorption in the rat, an effect not observed with $\mathrm{GH}$ treatment (Sibilia et al. 1999). This suggests that GH secretagogues may have GH-independent effects on bone in rodents. Interestingly, in rodents and in humans gastrectomy often results in osteopenia, although the mechanism for this is unclear (Bernstein et al. 2003). Furthermore, extracts from the oxyntic mucosa mobilize $\mathrm{Ca}^{2+}$ intracellular stores in osteoblast cell lines (Larsson et al. 2001), suggesting the presence of an osteotropic hormone(s) in the gastric mucosa, with ghrelin a possible candidate. Despite this, a recent study found that ghrelin did not induce a $\mathrm{Ca}^{2+}$ signal in a rat osteosarcoma cell line (Larsson et al. 2002). However, this does not exclude the possibility that ghrelin can signal via alternative intracellular pathways, and perhaps other receptors (Papotti et al. 2000, Baldanzi et al. 2002). In fact, three recent studies demonstrate that ghrelin has proliferative effects in rodent osteoblasts (Fukushima et al. 2005, Kim et al. 2005, Maccarinelli et al. 2005).

Since there are many physiological differences between rodents and humans we undertook to examine the role of ghrelin in regulating human osteoblast growth. In this study we have assessed the gene expression of ghrelin and its receptor subtypes in human bone cells. To further characterize the functional activity of ghrelin and its unacylated form, we have examined the effects of ghrelin and UAG on the growth of the well-characterized human osteoblast cell-line, SV-HFO (Weyts et al. 2003, Jansen et al. 2004, Eijken et al. 2005), and the possible intracellular signalling pathways involved in this process.

\section{Materials and Methods}

\section{Human femoral head biopsy}

Human bone material was obtained from femoral head biopsies of two osteoarthritic patients (bones 1 and 2, derived from separate patients). Bone marrow was removed and the inner cortical bone surfaces were carefully rinsed and homogenized using a Mikro Dismembrator S (Sartorius, Goettingen, Germany). RNA was isolated from the resulting homogenate as described below. Collection of human tissue was approved by the Erasmus MC Medical Ethical Commission (MEC No. 204-287).

\section{Cell culture}

A simian virus 40 (SV40)-immortalized human fetal osteoblast (SV-HFO) cell line (Weyts et al. 2003, Jansen et al. 2004, Eijken et al. 2005) was seeded at a density of 5500 cells $/ \mathrm{cm}^{2}$. The cells were cultured in Phenol Red-free $\alpha$-minimal essential medium (aMEM; Gibco BRL, Paisley, UK), supplemented with $100 \mathrm{IU} / \mathrm{ml}$ penicillin, $100 \mu \mathrm{g} / \mathrm{ml}$ streptomycin (Life Technologies, Breda, The Netherlands), $20 \mathrm{mM}$ HEPES, $1.8 \mathrm{mM} \mathrm{CaCl}_{2}$ and $10 \%$ heat-inactivated fetal calf serum (Gibco BRL) at $37^{\circ} \mathrm{C}$ in $5 \% \mathrm{CO}_{2}$ in a humidified atmosphere. Medium was changed every 2-3 days and after 1 week cells were trypsinized for further culture under different experimental conditions. For the differentiation study, the cells were seeded at a density of 10000 cells $/ \mathrm{cm}^{2}$. The cells were cultured in QMEM with $2 \%$ heat-inactivated charcoal-treated fetal calf serum at $37{ }^{\circ} \mathrm{C}$ in $5 \% \mathrm{CO}_{2}$. From day 2 onward cells were cultured in the presence of $10 \mathrm{mM} \beta$-glycerophosphate (Sigma, St Louis, MO, USA) and in the absence (non-differentiating conditions) or presence (differentiating conditions) of $10^{-6} \mathrm{M}$ dexamethasone (9 $\alpha$-fluoro-16 $\alpha$-methylprednisolone; Sigma). The medium was changed every $2-3$ days. Human ghrelin was obtained from Neosystems (Strasbourg, France) and human UAG was kindly provided by Theratechnologies (Montreal, Canada).

\section{DNA content}

For DNA measurements $100 \mu \mathrm{l}$ SV-HFO cell lysates were treated with $200 \mu \mathrm{l}$ heparin $(8 \mathrm{IU} / \mathrm{ml}$ in PBS) and $100 \mu \mathrm{l}$ RNase A $(50 \mu \mathrm{g} / \mathrm{ml}$ in PBS) for $30 \mathrm{~min}$ at $37 \mathrm{C}$. This was followed by adding $100 \mu \mathrm{l}$ ethidium bromide solution $(25 \mu \mathrm{g} / \mathrm{ml}$ in PBS). Samples were analyzed on the Wallac 1420 Victor2 (Perkin Elmer, Wellesley, MA, USA) using a $340 \mathrm{~nm}$ excitation filter and a $590 \mathrm{~nm}$ emission filter. Calf thymus DNA (Sigma) was used for standards.

\section{Alkaline phosphatase activity}

Alkaline phosphatase activity was assayed by determining the release of $p$-nitrophenol from $p$-nitrophenylphosphate $(20 \mathrm{mM}$ in $1 \mathrm{M}$ diethanolamine buffer supplemented with $1 \mathrm{mM} \mathrm{MgCl}$ at $\mathrm{pH} 9 \cdot 8$ ) in the SV-HFO cell lysates for $10 \mathrm{~min}$ at $37{ }^{\circ} \mathrm{C}$. The reaction was stopped by adding $0.06 \mathrm{M} \mathrm{NaOH}$. Absorption was measured at $405 \mathrm{~nm}$. Results were adjusted for DNA content of the corresponding cell lysates.

\section{Mineralization}

SV-HFO cell lysates were incubated overnight in $0 \cdot 24 \mathrm{M}$ $\mathrm{HCl}$ at $4{ }^{\circ} \mathrm{C}$. Calcium content was determined colorimetrically with a calcium assay kit (Sigma) according to 
the manufacturer's description. Results were adjusted for DNA content of the corresponding cell lysates.

\section{RNA isolation, $c D N A$ synthesis and real-time PCR}

Total RNA from bone biopsies and cultured osteoblasts was isolated using RNA-Bee solution (Tel-Test, Friendswood, TX, USA). mRNA was subsequently isolated from total RNA using the Oligotex Direct mRNA mini kit (Qiagen). RNA was quantified using a Ribogreen assay (Molecular Probes, Eugene, OR, USA). One $\mu \mathrm{g}$ total RNA was reverse transcribed into cDNA, using $0 \cdot 5 \mu \mathrm{g}$ oligo $(\mathrm{dT})_{18}, 0 \cdot 2 \mu \mathrm{g}$ random hexamer primers and Moloney murine leukemia virus reverse transcriptase according to the protocol of the manufacturer (MBI Fermentas, St Leon-Rot, Germany). Five ng (biopsies) or $20 \mathrm{ng}$ (differentiating and non-differentiating SV-HFO cells at 7,14 and 21 days of culture) of cDNA was then assayed for ghrelin, GHS-R1a and GHS-R1b genes using one-step TaqMan real-time PCR with an ABI Prism 7700 sequence-detection system (PE Biosystems, Rotkreuz, Switzerland). The strategy for distinguishing GHS-R1a and GHS-R1b splice variants and PCR assay conditions were similar to those described by Gnanapavan et al. (2002). The presence of GHS-R1b mRNA in osteoblasts was also confirmed using cDNAs derived from poly $(\mathrm{A})^{+}$ RNA samples from all culture time points with and without dexamethasone treatment. Reactions without reverse transcriptase were included to check for genomic DNA contamination. Since GHS-R1a was not detected in total RNA, SV-HFO mRNA was reverse transcribed and assayed for GHS-R1a gene expression by real-time PCR using alternative primers and a locked nucleic acid (LNA) probe (Exiqon A/S, Vedbaek, Denmark). Samples were also processed without reverse transcriptase as negative controls. Samples were assayed in duplicate and corrected for GAPDH mRNA. The data presented for ghrelin and GHS-R gene expression in SV-HFO cells represent analyses of RNA from four different, independent experiments of two cultures each.

Primer and probe sequences were as follows: ghrelin, forward 5'-GGGCAGAGGATGAACTGGAA-3', reverse 5'-CCTGGCTGTGCTGCTGGTA-3', probe $5^{\prime}$-FAMTCCGGTTCAACGCC-TAMRA-3'; GHS-R1a, forward 5'-ACCAGAACCACAAGCAAACC-3', reverse 5'-AGGGTTCGAATCCCAGAAGT-3', probe 5'-FAMCTGCTGGCTCCCCTTCCACG-TAMRA-3'; GHSR1b, forward 5'-TCGTGGGTGCCTCGCT-3', reverse 5'-GCTGAGACCCACCCAGCA-3', probe 5'-AGGGA CCAGAACCACAAGCAAACCG-3'; GAPDH, forward 5'-ATGGGGAAGGTGAAGGTCG-3', reverse, 5'-TAA AAGCAGCCCTGGTGACC-3', probe 5'-FAM-CGCC CAATACGACCAAATCCGTTGAC-TAMRA-3' (FAM: carboxyflurorescein; TAMRA; carboxytetramethylrhodame). Sequences of LNA probe and primers: GHS-R1a LNA probe, 5'-CTGGCTCC-3'; GHS-R1a, forward 5'-GCA

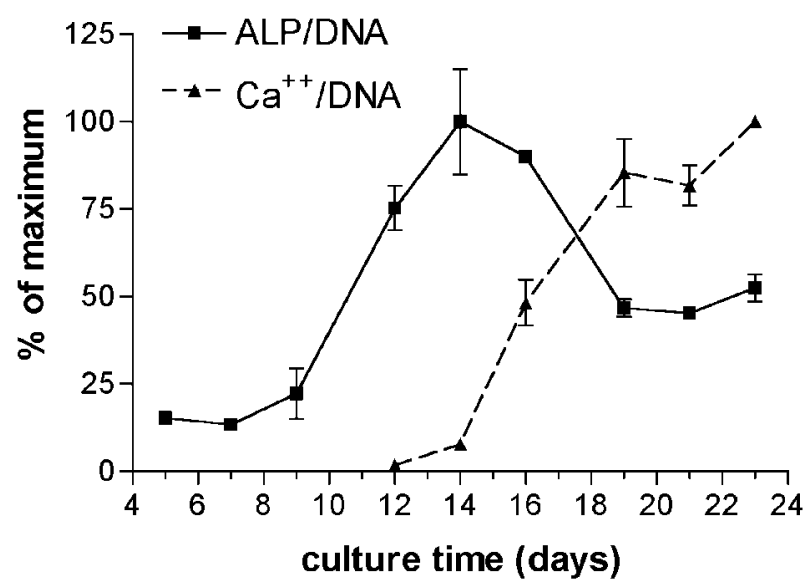

Figure 1 Alkaline phosphatase (ALP) activity and mineralization corrected for DNA content (ALP/DNA and $\mathrm{Ca}^{++} / \mathrm{DNA}$ ) in human osteoblasts during culture in media containing dexamethasone. Alkaline phosphatase activity peaked at day 14 then declined towards the end of the 23-day culture period. Mineralization was initiated at day 14 and increased up to day 19 where it plateaued. In the absence of dexamethasone, cultures showed no evidence of osteoblast differentiation and mineralization. Data are derived from duplicate samples in a typical experiment.

AACCGTGAAAATGCTG-3'; reverse 5'-AAATATCG CCCTACGTGGAA-3'. Spleen total RNA was used as a positive control for ghrelin and GHS-R1b expression, since it is known to express these genes (Gnanapavan et al. 2002). Pituitary total RNA was used as a positive control for GHS-R1a gene expression. Data presented are relative mRNA levels calculated as $2^{-\Delta \mathrm{Ct}} \times 10^{6}$ where $\Delta C t=C t_{\text {gene of interest }}-C t_{\mathrm{GAPDH}}$ (Bustin \& Nolan 2004). Samples in which no amplified product could be detected by cycle 40 were considered not to express the gene being assayed.

\section{Ghrelin enzyme immunoassay}

Human osteoblasts were cultured for 24 and $72 \mathrm{~h}$ in serum-free medium. Ghrelin was measured in the conditioned media using an enzyme immunoassay kit that measures both acylated and unacylated forms of human ghrelin (Total Ghrelin kit; Phoenix Europe, GMBH, Karlsruhe, Germany). Medium that had not been conditioned was also assayed using this kit to check the specificity of the assay in our hands, and the presence of exogenous ghrelin in the medium. Total protein was determined using the BioRad protein assay reagent (BioRad, Hercules, CA, USA).

\section{Cell-growth experiments}

Proliferation was examined by $\left[{ }^{3} \mathrm{H}\right]$ thymidine uptake measurements. SV-HFO cells were seeded into 96-well 

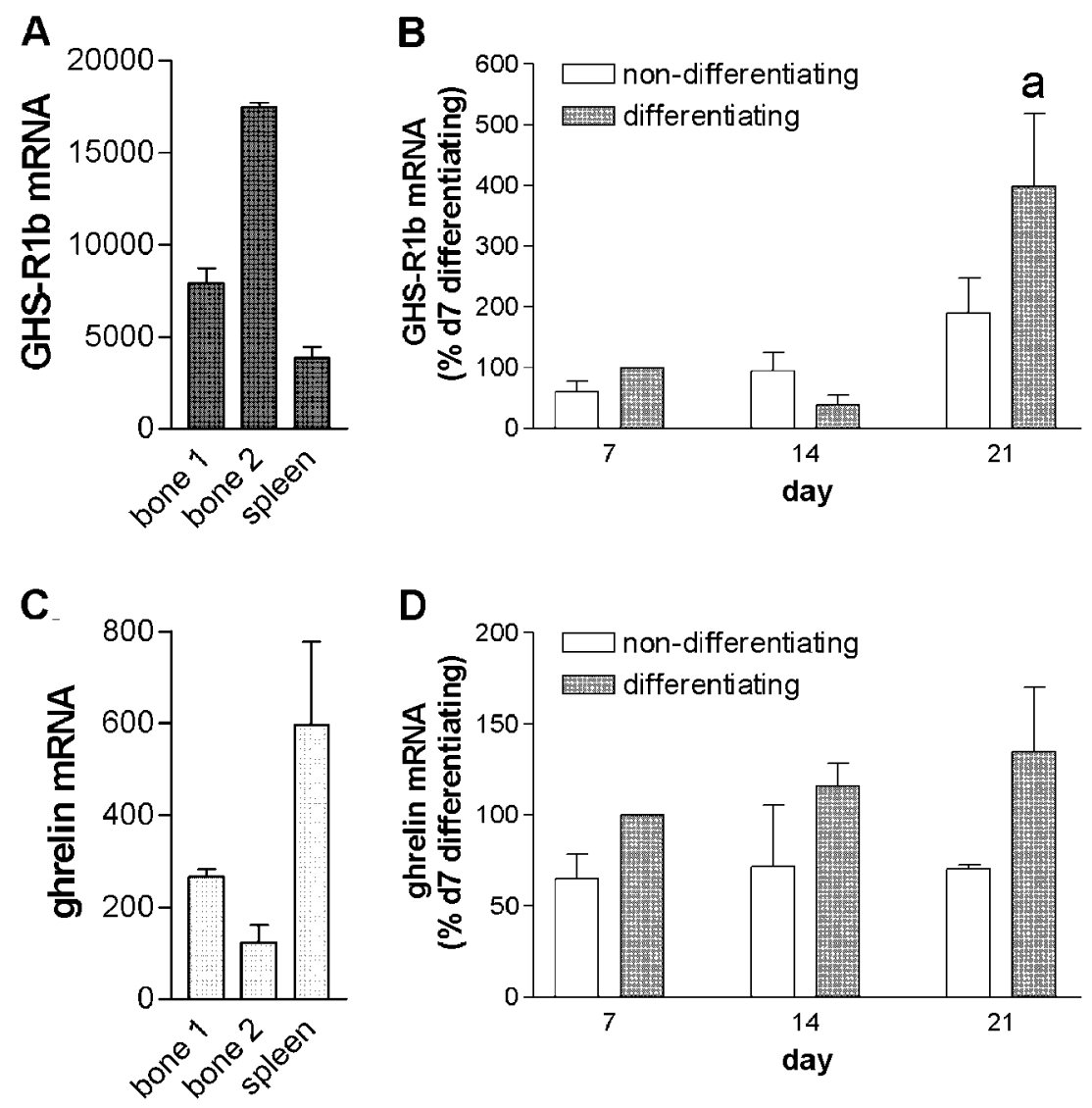

Figure 2 GHS-R1b mRNA expression in human bone. (A) Relative quantitation of GHS-R1b mRNA (see the Materials and Methods section) in human osteoarthritic bone biopsy samples compared with that in human spleen. (B) Relative expression of GHS-R1b mRNAs in non-differentiating and differentiating SV-HFO osteoblasts. (a, $P<0.005$ versus differentiating cells at day $7(d 7))$. (C) Relative quantitation of ghrelin mRNA in human osteoarthritic bone biopsy samples compared with that in human spleen. (D) Relative expression of ghrelin mRNAs in non-differentiating and differentiating SV-HFO osteoblasts. Bone 1 and bone 2 refer to samples from two different subjects. SV-HFO data are derived from four separate experiments and are corrected for GAPDH mRNA expression (see the Materials and Methods section). GHS-R1a mRNA was undetectable in these samples. Functionality of the GHS-R1a TaqMan primer/probe set was confirmed using human pituitary RNA (see the Results section).

plates as described above, in differentiating and nondifferentiating conditions. After culture for 5, 12 or 19 days the cells were treated for $20 \mathrm{~h}$ with ghrelin or UAG at various concentrations in 10-27 replicate wells per treatment at day 5 (thymidine assay on day 6), and 6-10 replicate wells at days 12 and 19 (thymidine assays on days 13 and 20).

Experiments with extracellular-signal-regulated kinase (ERK) and phosphoinositide-3 kinase (PI3K) inhibitors were also started on day $5 \quad(n=20)$. Cells were preincubated for $40 \mathrm{~min}$ with vehicle $(0 \cdot 1 \%$ DMSO; Sigma), $10 \mu \mathrm{M}$ U0126 (Promega, Madison, WI, USA), $35 \mu \mathrm{M}$ PD98059 or $100 \mathrm{nM}$ wortmannin (Sigma). These concentrations were found to have no effect on basal thymidine uptake and are similar to those used in other studies involving osteoblasts (e.g. Grey et al. 2002, Jansen et al. 2004, Kim et al. 2005, Osyczka \& Leboy 2005). These initial treatments were replaced with media containing vehicle or inhibitor, as appropriate, with or without ghrelin or UAG. Cells were then incubated for $20 \mathrm{~h}$. Subsequently (culture day 6), $\left[{ }^{3} \mathrm{H}\right]$ thymidine (Amersham, Little Chalfont, Bucks, UK) was added to a concentration of $1 \mu \mathrm{Ci} / \mathrm{ml}$ and incubated for a further $7 \mathrm{~h}$. Cells were then harvested onto glass-fibre mats (TomtecHarvester 96; Hamden, CT, USA) and radioactivity measured with a Wallac MicroBeta scintillation counter. 

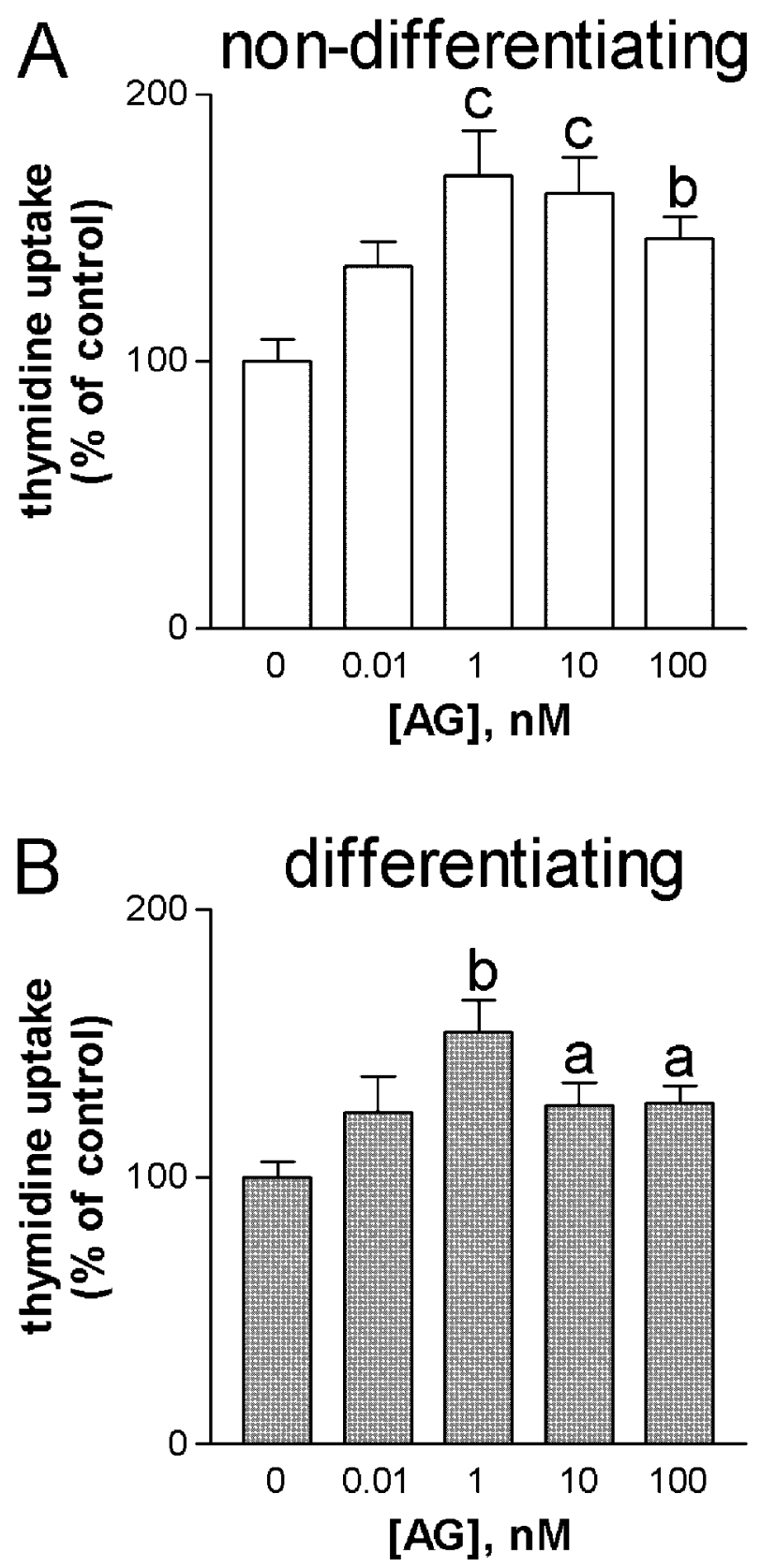

Figure 3 Ghrelin (AG) dose-dependently stimulates thymidine uptake by human osteoblasts. Cells were treated for $20 \mathrm{~h}$ with ghrelin, starting on day 5 , then thymidine uptake was measured following $7 \mathrm{~h}$ incubation on day 6 . (A) Non-differentiating cells $(n=10-20)$. (B) Differentiating cells $(n=10-20 ; a, P<0 \cdot 05$;

b, $P<0.005 ; \mathrm{c}, P<0.0005$ versus $0 \mathrm{nM}$ controls).

\section{ERK phosphorylation assay}

ERK activation was determined using a fast activated cell enzyme-linked immunosorbent assay kit (FACE; ActiveMotif, Carlsbad, CA, USA). Briefly, osteoblasts were seeded into 96-well plates at a density of $10000 \mathrm{cells} / \mathrm{cm}^{2}$ as described above, in non-differentiating medium. At day 6 , cells were treated with medium lacking or containing $10 \mathrm{nM}$ ghrelin or $100 \mathrm{nM}$ UAG for $5 \mathrm{~min}$. The cells were then fixed and incubated with specific antiphosphorylated ERK antibodies followed by incubation with a secondary horseradish peroxidase-conjugated antibody. The levels of phosphorylated ERK were quantified using a colorimetric readout and are expressed as the absorbance at $450 \mathrm{~nm}$ measured in each well.

\section{Statistical analysis}

Statistical analyses were performed with StatView5 for Macintosh (SAS Institute, Cary, NC, USA). Results were tested for statistical significance using analysis of variance (ANOVA), followed by Fisher's protected least-significant difference post-hoc test. Data are presented as means \pm S.E.M.

\section{Results}

\section{Osteoblast differentiation}

During SV-HFO cell culture, osteoblast differentiation was monitored by measuring DNA levels, alkaline phosphatase activity and mineralization. In the absence of dexamethasone alkaline phosphatase activity remained very low throughout the whole 23-day culture period. In contrast, cultures that were treated continuously with dexamethasone showed an increase of alkaline phosphatase activity, which peaked around day 14 (Fig. 1). In these dexamethasone-treated cultures mineralization was initiated around day 14 of culture and increased further up to day 19, after which it levelled off (Fig. 1). In the absence of dexamethasone, cultures showed no evidence of osteoblast differentiation and mineralization. Dexamethasonetreated and non-dexamethasone-treated cell cultures will be referred to as differentiating and non-differentiating osteoblasts, respectively.

\section{Expression of the GHS-R splice variants and ghrelin in human bone cells}

Like an earlier study of human bone marrow using RNase protection assay with poly(A) ${ }^{+}$RNA (Guan et al. 1997), GHS-R1a mRNA was not detected in the bone samples, although identical TaqMan assays of human pituitary RNA produced positive amplification data (GAPDH ratio of $\sim 1120\left(2^{-\Delta \mathrm{Ct}} \times 10^{6}\right)$ from $20 \mathrm{ng} \mathrm{cDNA}$; see Materials and Methods section). However, GHS-R1b mRNA was detected in femoral bone (Fig. 2A) at $200-450 \%$ of its level of expression in spleen.

Bone biopsies probably contain a mixed population of cell types including osteoblasts. Therefore, to clarify whether the GHS-R subtype mRNAs are expressed 
in osteoblasts, we measured their expression by real-time PCR in cultured human osteoblasts. Like the biopsies, no GHS-R1a mRNA was detectable in total RNA from human osteoblast cultures at any of the time points examined. To examine this negative observation further we ran real-time PCRs of cDNAs derived from mRNA using an alternative primer set and an LNA probe. Again, no GHS-R1a mRNA expression was detected. In contrast, human osteoblasts expressed GHS-R1b mRNA and the expression markedly increased during differentiation, reaching $400 \%(P=0.004)$ at day 21 of levels found in day 7 cultures (Fig. 2B). GHS-R1b gene expression did not increase significantly during the culture of non-differentiating cells.

It was of interest to determine whether ghrelin was expressed locally in bone. Ghrelin mRNA was expressed in femoral bone (Fig. 2C) at $20-45 \%$ of its level of expression in spleen. To determine the specificity of ghrelin expression in osteoblasts we next examined the expression of ghrelin in cultured human osteoblasts during differentiation. Like the bone biopsies, ghrelin mRNA was expressed in osteoblasts, suggesting that at least part of the gene expression we observed in adult bone biopsies was derived from osteoblast cells (Fig. 2D). The level of ghrelin gene expression, although tending to increase, did not change significantly during culture of the cells in either differentiating or non-differentiating conditions (Fig. 2D).

To test whether the level of gene expression we observed had possible physiological meaning, total ghrelin (ghrelin and UAG) was measured in serum-free medium conditioned by human osteoblasts for 24 and $72 \mathrm{~h}$ using a human total ghrelin enzyme immunoassay. At $24 \mathrm{~h}$ ghrelin occurred at $77 \mathrm{pg} / \mathrm{mg}$ protein, and in $72 \mathrm{~h}$ cultures it was approximately 5 -fold higher at $382 \mathrm{pg} / \mathrm{mg}$ protein (means of two experiments at each time point, accumulated concentrations measured between approximately $3 \cdot 5$ and $6 \mathrm{pM})$. The serum-free medium used for conditioning contained no detectable ghrelin.

\section{The stimulation of osteoblast proliferation by ghrelin and $U A G$}

We next examined whether ghrelin and its unacylated form could modulate the growth characteristics of osteoblasts during early stages of culture when they are rapidly proliferating and start to differentiate. To do this human osteoblasts were cultured for 5 days either in differentiating or non-differentiating conditions and then thymidine uptake was measured to determine their rate of proliferation.

Thymidine uptake was significantly and dosedependently stimulated by ghrelin relative to untreated controls, reaching maxima at $1 \mathrm{nM}$ in both nondifferentiating $(170 \%$ of untreated controls, $P<0 \cdot 0001$; Fig. 3A) and differentiating (155\% of untreated controls,
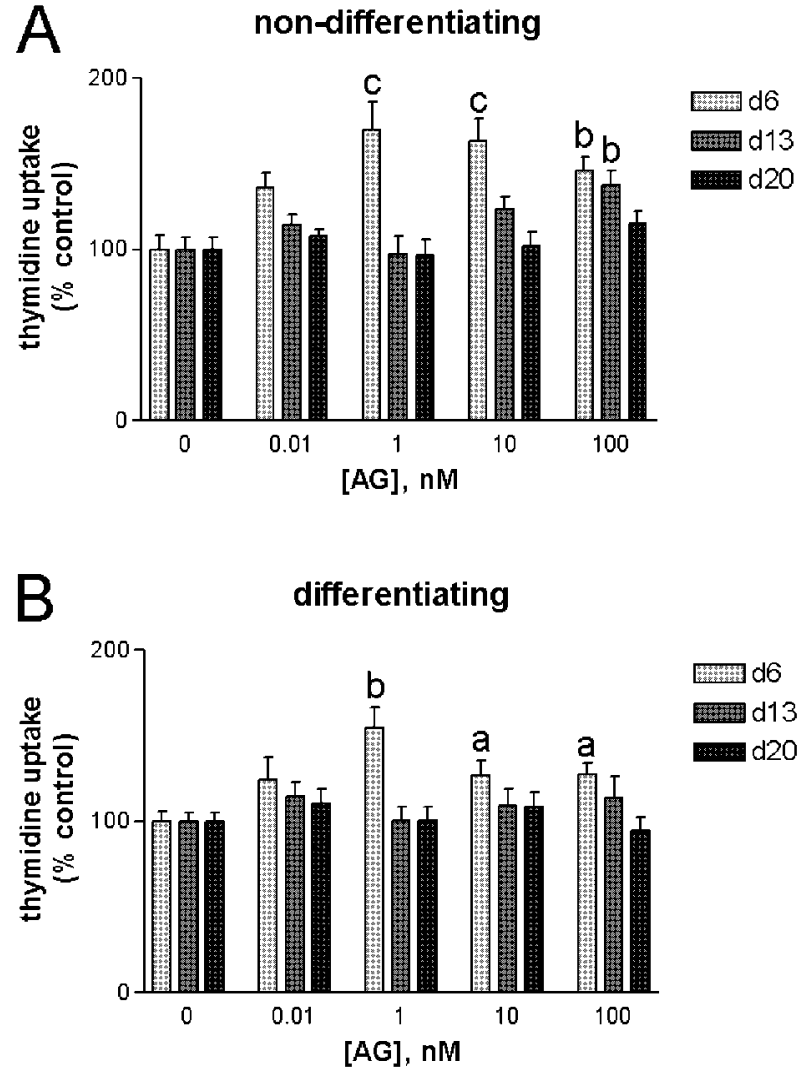

Figure 4 The proliferative effect of ghrelin (AG) is dependent on time in culture and state of differentiation. Cells were treated for $20 \mathrm{~h}$ with ghrelin, starting on days 5 ( $n=10-27$ replicates per treatment), 12 or 19 ( $n=6-10$ replicates per treatment), then thymidine uptake was measured following $7 \mathrm{~h}$ incubation on days (d) 6, 13 and 20. (A) In non-differentiating cells the effect of ghrelin on thymidine uptake generally declines with time in culture, with no significant effect of ghrelin detectable during the third week. (B) In differentiating osteoblasts the response to ghrelin disappears within 2 weeks of culture $(a, P<0 \cdot 05$; $\mathrm{b}, \mathrm{p} \leq 0.005 ; \mathrm{c}, \mathrm{P}<0.0005$ versus $0 \mathrm{nM}$ controls).

$P<0 \cdot 001$; Fig. 3B) cultures. Ghrelin $(10 \mathrm{nM})$ was also confirmed to increase cellular DNA content to $144 \%$ $(P<0.007)$ and $119 \% \quad(P<0.02)$ of control levels in non-differentiating and differentiating cultures after $72 \mathrm{~h}$.

We next examined whether the proliferative effect of ghrelin on the SV-HFO cells was dependent on culture time and whether or not the cells had been induced to differentiate. In non-differentiating cells the proliferative response declined with time in culture, with a decline in response at day 13 and eventually leading to loss of a significant effect of ghrelin, even at $100 \mathrm{nM}$, in cultures at day 20 (Fig. 4). The reduction in the proliferative effect of ghrelin was even more pronounced in differentiating cultures, which were already less responsive than nondifferentiating cells by day 6 (see Fig. 3), and had completely lost their ability to respond to ghrelin by day 13 . 


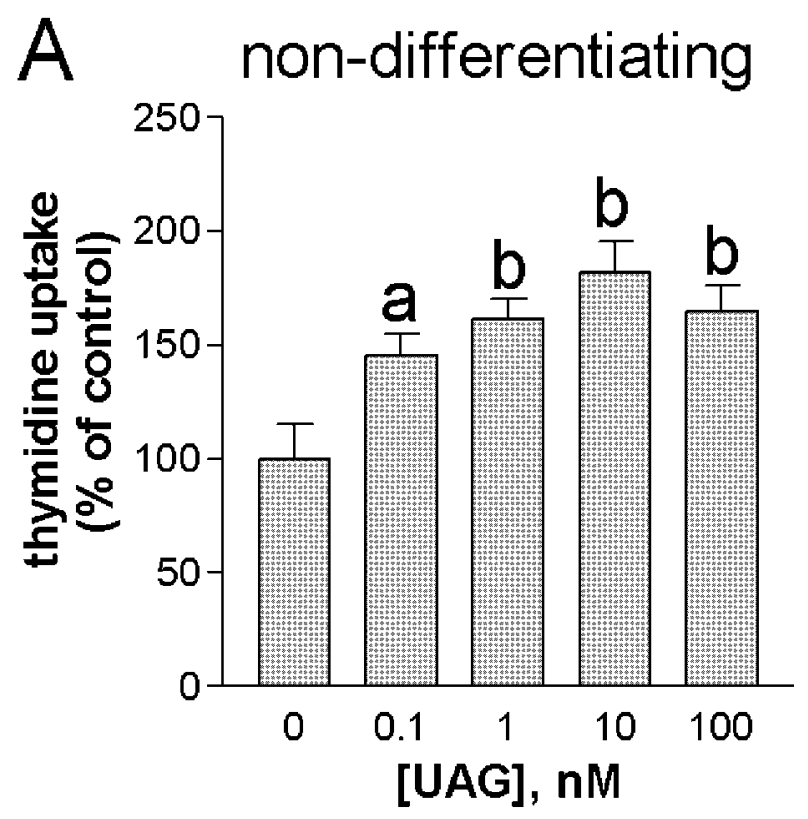

B differentiating

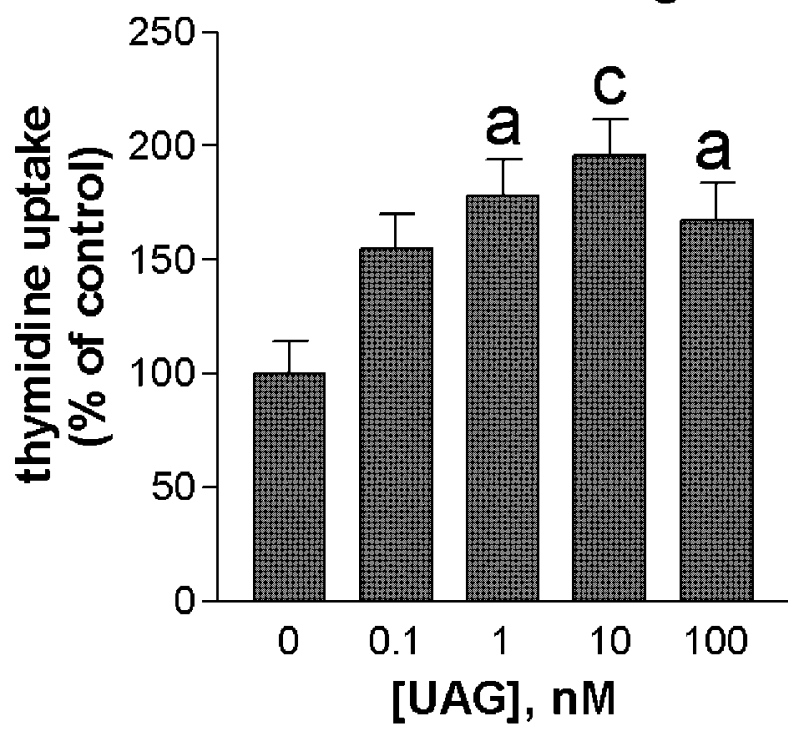

Figure 5 UAG dose-dependently stimulates thymidine uptake by human osteoblasts. Starting on day 5, cells were treated for $20 \mathrm{~h}$ with UAG, then thymidine uptake was measured following $7 \mathrm{~h}$ incubation on day 6. (A) Non-differentiating human osteoblasts respond to UAG from $0 \cdot 1 \mathrm{nM}$, reaching a plateau at $10 \mathrm{nM}(182 \%$ of controls). (B) Differentiating osteoblasts also respond maximally to $10 \mathrm{nM} \cup \mathrm{AG}$, but with greater amplitude (195\% of controls; $n=10-27 ; \mathrm{a}, P<0 \cdot 05 ; \mathrm{b}, P \leq 0 \cdot 005 ; \mathrm{c}, P<0.0005$ versus $0 \mathrm{nM}$ controls $)$.

UAG also had a marked dose-dependent inductive effect on thymidine uptake in both non-differentiating and differentiating cells at day 6 of culture (Fig. 5). UAG had maximal effect at $10 \mathrm{nM}(180 \%$ of controls in nondifferentiating cells $(P=0 \cdot 0003)$ and $195 \%$ of controls in differentiating cells $(P=0 \cdot 0003))$. Furthermore, the response to UAG declines with time in culture and with differentiation in a way that is comparable to the ghrelin response, suggesting that the mechanism of response is similar, if not identical (Fig. 6). Studies on alkaline phosphatase activity and mineralization during the 3-week culture period demonstrated that neither ghrelin nor UAG affect these two processes (data not shown).

\section{Signaling pathways for ghrelin and UAG proliferative activity}

Ghrelin in particular, but also UAG, have been shown to activate mitogen-activated protein kinase (MAPK) and PI3K pathways in other cell types (e.g. Baldanzi et al. 2002, Kim et al. 2004, Nanzer et al. 2004). ERK and PI3K are important components of signalling pathways that are often directly involved in proliferative responses of cells to growth factors. Therefore, the possible involvement of these pathways was investigated by utilizing specific inhibitors of ERK activation (U0126 and PD98059) and PI3K activity (wortmannin) at concentrations that had no significant effect on basal cell proliferation. Since the most potent effects of ghrelin and UAG on proliferation occurred in non-differentiating osteoblasts we tested the inhibitors under these conditions using the peptides at concentrations that had been confirmed to induce proliferation. All three inhibitors blocked or suppressed the proliferative response of human osteoblasts to ghrelin (Fig. 7A) and UAG (Fig. 7B).

To further confirm the involvement of the MAPK signalling pathway in the proliferative effects of ghrelin and UAG we examined the acute effects of these peptides on the phosphorylation of ERK by ELISA. We found that ghrelin and UAG (10 and $100 \mathrm{nM}$, respectively) significantly stimulated the phosphorylation of ERK relative to their untreated controls $(123 \pm 8 \cdot 6$ and $124 \pm 9 \cdot 1 \%$, respectively; $P<0 \cdot 05$, by ANOVA) in serum-starved human osteoblasts within 5 min of treatment (Fig. 8).

\section{Discussion}

The current study demonstrates ghrelin gene expression in human bone tissue, suggesting that, like rodents, ghrelin may have auto-/paracrine activity in human bone, in addition to the endocrine activity of gastric-derived hormone. However, the absence of GHS-R1a suggests that an auto-/paracrine effect might be mediated by an alternative receptor in human bone. The presence of a non-type-1a GHS-R is also suggested by the response of the cells to UAG. In rat osteoblasts, GHS-R1a protein was detected and thus may mediate the proliferative effects of ghrelin observed in these cells (Fukushima et al. 2005, Maccarinelli et al. 2005). This observation suggests species 


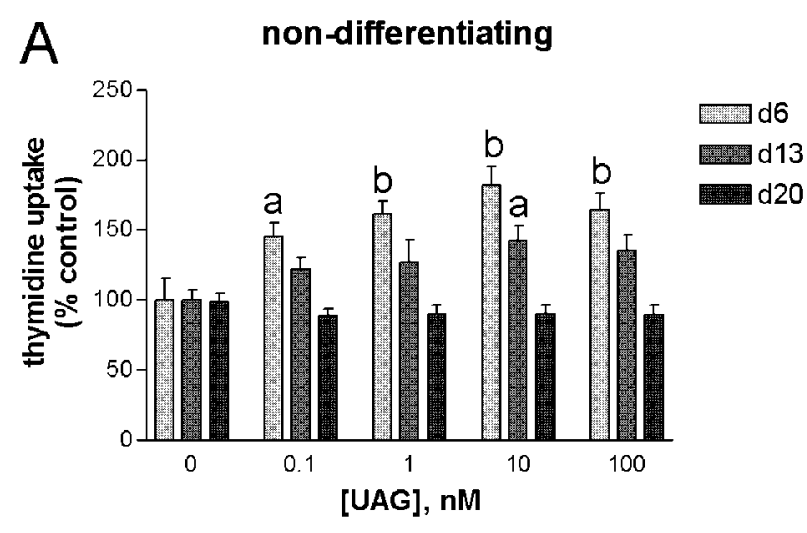

B
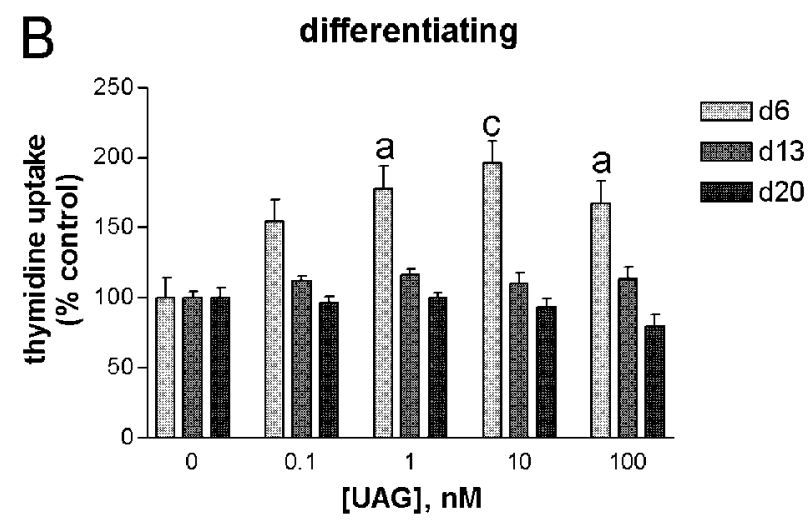

Figure 6 The proliferative effect of UAG, like ghrelin, is dependent on time in culture and state of differentiation. Cells were treated for $20 \mathrm{~h}$ with UAG, starting on days 5 ( $n=10-27$ replicates per treatment), 12 or 19 ( $n=6-10$ replicates per treatment), then thymidine uptake was measured following $7 \mathrm{~h}$ incubation on days (d) 6, 13 and 20. (A) In non-differentiating cells the effect of UAG on thymidine uptake generally declines with time in culture having only approximately $50 \%$ of its effect at all doses at week two, and with no significant effect detectable during the third week. (B) In differentiating osteoblasts the response to UAG disappears after the first week of culture $(a, P<0.05 ; b, P \leq 0.005 ; c, P<0.0005$ versus $0 \mathrm{nM}$ controls on the same day).

differences between rodent and human bone in the expression of the cognate receptor.

The expression in human bone biopsies and the changes in GHS-R1b mRNA are intriguing. GHS-R1b is almost identical to GHS-R1a but is truncated after transmembrane domain 5 , and current evidence demonstrates that this receptor does not stimulate an intracellular signalling pathway (Howard et al. 1996, Feighner et al. 1998). Mutational analysis of the GHS-R suggests that the ligand-binding site (at least of synthetic GHS) involves residues D99, C116 and E124, which are located in transmembrane domains 2 and 3 and extracellular loop 1 (Feighner et al. 1998). So it is conceivable that GHS-R1b can either bind ligand or modify interaction of the ligand with the cognate receptor. There is some evidence for the latter where overexpression of GHS-R1b appears to antagonize the response of GHS-R1a to synthetic GH secretagogues (Chan \& Cheng 2004).

An explanation for loss of a proliferative response to both peptides with time in culture and state of differentiation is lacking. It could be related to differentiationrelated changes in receptor signalling pathways. In this respect it is intriguing that there appears to be an inverse relationship between the loss of proliferative response to ghrelin and the increased expression of GHS-R1b. We found that GHS-R1b gene expression increased particularly in the last week of culture, and was lower in non-differentiating than differentiating cells at this time. A similar stimulatory effect of glucocorticoids on GHS-R gene expression has been demonstrated in the pituitaries of rats (Tamura et al. 2000). It is tempting to speculate that the increase in GHS-R1b during dexamethasone-induced differentiation may correspond with an inhibitory effect on ghrelin-induced cell growth.

From the current data it is clear that ghrelin is expressed by osteoblasts. Moreover, ghrelin and UAG are potent stimulators of proliferation in human osteoblasts, being effective in the nanomolar range. Inhibition of these proliferative effects by inhibitors of ERK and PI3K, and the activation of the MAPK pathway through phosphorylation of ERK, suggests the requirement for these pathways in both ghrelin and UAG signalling in human osteoblasts, and indicates a similar mechanism to that described for cardiomyocytes (Baldanzi et al. 2002) and hepatoma cells (Murata et al. 2002). However, the mechanism by which the proliferative effects of ghrelin and UAG on osteoblasts are initiated is unclear since GHSR1a mRNA is not expressed at detectable levels in these cells, and GHS-R1b has been demonstrated to be nonfunctional, at least through activation of a $\mathrm{Ca}^{2+}$ pathway (Howard et al. 1996). Recently, it has been demonstrated that UAG stimulates adipogenesis in vivo, and that ghrelin has similar effects that appear to be independent of GHS-R1a (Thompson et al. 2003). However, the mechanism, or receptor, which mediates the response to these peptides remains unknown. The involvement of both MAPK and PI3K pathways does not exclude the possibility that receptor types other than a G-protein-coupled receptor are involved in transducing the response. It is also possible that an indirect mechanism is involved, as has been suggested for prostate cells, where cell proliferation could be mediated via an auto-/paracrine pathway involving other growth factors (Jeffery et al. 2003). Even so, a receptor for ghrelin and UAG would still be necessary to stimulate such an intermediate mechanism. Therefore, it will be a challenge to identify a new receptor for ghrelin in peripheral tissues and to define its mode of action.

Indirect evidence for our hypothesis that a receptor other than GHS-R1a may be involved in bone metabolism is the finding that GHS-R1a homozygous knockout mice do not have a significantly altered bone phenotype 

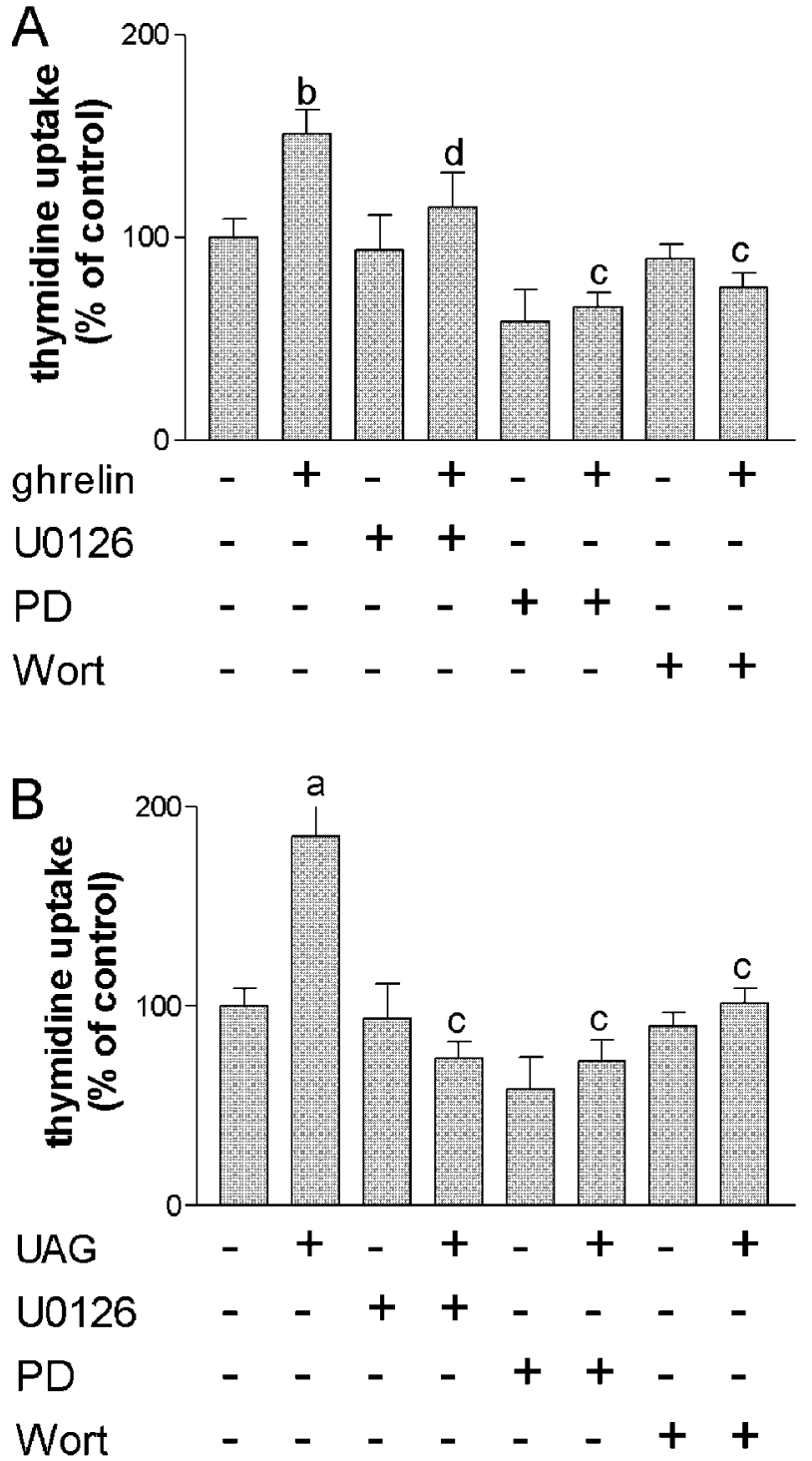

Figure 7 The proliferative responses to ghrelin (A) and UAG (B) are suppressed by blockade of ERK and PI3K activities. The data are expressed as the percentage of thymidine uptake relative to controls treated with vehicle (DMSO). ERK signalling was inhibited by $10 \mu \mathrm{M} \cup 0126$ and 35 $\mu \mathrm{M}$ PD98059 (PD), and PI3K signalling by $100 \mathrm{nM}$ wortmannin (Wort). Inhibitor concentrations were found to have no significant independent effect on cellular uptake of thymidine ( $\mathrm{a}$ and $\mathrm{b}, P<0.001$ and $P<0.01$ relative to control, respectively; $\mathrm{c}$ and $\mathrm{d}: P<0.001$ and $P<0.001$ relative to respective ghrelin- or UAG-treated controls). Ghrelin and UAG were used at 10 and $100 \mathrm{nM}$, respectively. Data were derived from two separate experiments ( $n=20$ for controls and $n=10$ for each treatment).

(Sun et al. 2004), as assessed by bone mineral density (BMD) and bone mineral content (BMC). Our findings suggest that ghrelin only has significant proliferative effects early on in osteoblast cultures rather than direct effects on

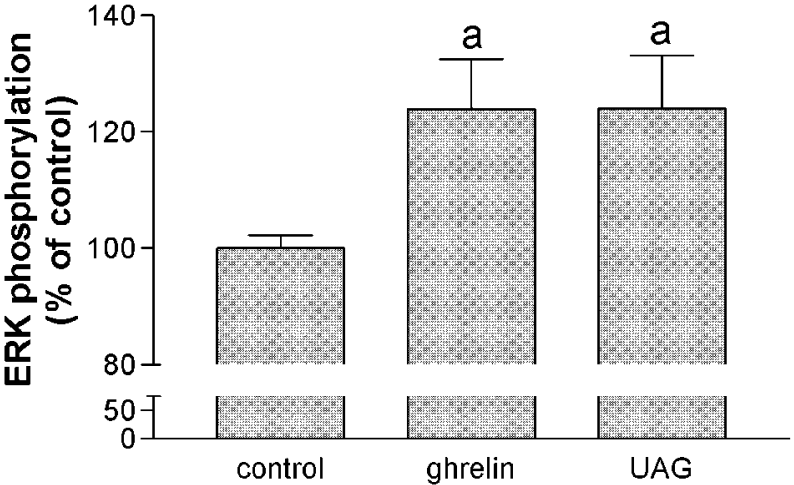

Figure 8 Ghrelin and UAG rapidly stimulate the phosphorylation of ERK in human osteoblasts. SV-HFO cells were serum starved for $16 \mathrm{~h}$, then treated for $5 \mathrm{~min}$ in the absence $(n=8)$ or presence of $10 \mathrm{nM}$ ghrelin $(n=4)$ or $100 \mathrm{nM}$ UAG $(n=8)$. Cells were then assayed for phosphorylated ERK using a colorimetric FACE ERK1/2 cell-based ELISA. Data are presented as the percentage of control values $(\mathrm{a}, P<0 \cdot 05$ relative to vehicle control).

osteoblast differentiation. Therefore, it is possible that in vivo ghrelin acts primarily on the proliferation of osteoblast progenitors and/or preosteoblasts rather than mature osteoblasts. However, the lack of phenotype in the gene-deleted animals may be linked to redundancy in regulatory mechanisms that operate during this period of osteoblast development. Similar compensatory mechanisms may be at work in the ghrelin-knockout mice, which also have no obvious bone phenotype, again as assessed only by BMD and BMC (Sun et al. 2003). Compensation for the loss of ghrelin in these mice is evidenced by the lack of effect on appetite, food intake and body composition (Sun et al. 2003, 2004, Wortley et al. 2004). However, BMD and BMC are relatively crude markers of bone turnover, and it would be of interest to examine in greater detail bone morphology and markers of bone turnover in these animals.

The current study clearly reveals that ghrelin is produced by human bone cells and that ghrelin and UAG stimulate proliferation of human osteoblasts via a mechanism that involves activity of the MAPK and PI3K signalling pathways. These data uncover a new regulatory mechanism for bone metabolism in humans. The potent effects of UAG suggest a new, as yet undefined, receptor/signalling pathway in bone.

\section{Funding}

The study was supported by the Netherlands Organization for Scientific Research (NWO grant 912-03022). The authors declare that there is no conflict of interest that would prejudice the impartiality of this scientific work. 


\section{References}

Andreis PG, Malendowicz LK, Trejter M, Neri G, Spinazzi R, Rossi GP \& Nussdorfer GG 2003 Ghrelin and growth hormone secretagogue receptor are expressed in the rat adrenal cortex: Evidence that ghrelin stimulates the growth, but not the secretory activity of adrenal cells. FEBS Letters 536 173-179.

Ariyasu $\mathrm{H}$, Takaya K, Iwakura $\mathrm{H}$, Hosoda $\mathrm{H}$, Akamizu T, Arai Y, Kangawa K \& Nakao K 2004 Transgenic mice overexpressing des-acyl ghrelin show small phenotype. Endocrinology 146 355-364.

Baldanzi G, Filigheddu N, Cutrupi S, Catapano F, Bonissoni S, Fubini A, Malan D, Baj G, Granata R, Broglio F et al. 2002 Ghrelin and des-acyl ghrelin inhibit cell death in cardiomyocytes and endothelial cells through ERK1/2 and PI 3-kinase/AKT. Journal of Cell Biology 159 1029-1037.

Bernstein CN, Leslie WD \& Leboff MS 2003 AGA technical review on osteoporosis in gastrointestinal diseases. Gastroenterology 124 795-841.

Broglio F, Arvat E, Benso A, Gottero C, Prodam F, Granata R, Papotti M, Muccioli G, Deghenghi R \& Ghigo E 2002 Ghrelin: much more than a natural growth hormone secretagogue. Israeli Medical Association Journal 4 607-613.

Bustin SA \& Nolan T 2004 Pitfalls of quantitative real-time reverse-transcription polymerase chain reaction. Journal of Biomolecular Technology 15 155-166.

Chan CB \& Cheng CH 2004 Identification and functional characterization of two alternatively spliced growth hormone secretagogue receptor transcripts from the pituitary of black seabream Acanthopagrus schlegeli. Molecular \& Cellular Endocrinology 214 81-95.

Eijken M, Hewison M, Cooper MS, de Jong FH, Chiba H, Stewart PM, Uitterlinden AG, Pols HA \& van Leeuwen JP 200511 beta-Hydroxysteroid dehydrogenase expression and glucocorticoid synthesis are directed by a molecular switch during osteoblast differentiation. Molecular Endocrinology 19 621-631.

Feighner SD, Howard AD, Prendergast K, Palyha OC, Hreniuk DL, Nargund R, Underwood D, Tata JR, Dean DC, Tan CP et al. 1998 Structural requirements for the activation of the human growth hormone secretagogue receptor by peptide and nonpeptide secretagogues. Molecular Endocrinology 12 137-145.

Fukushima N, Hanada R, Teranishi H, Fukue Y, Tachibana T, Ishikawa H, Takeda S, Takeuchi Y, Fukumoto S, Kangawa K et al. 2005 Ghrelin directly regulates bone formation. Journal of Bone Mineral Research 20 790-798.

Gnanapavan S, Kola B, Bustin SA, Morris DG, McGee P, Fairclough P, Bhattacharya S, Carpenter R, Grossman AB \& Korbonits M 2002 The tissue distribution of the mRNA of ghrelin and subtypes of its receptor, GHS-R, in humans. Journal of Clinical Endocrinology \& Metabolism 872988.

Grey A, Chen Q, Callon K, Xu X, Reid IR \& Cornish J 2002 The phospholipids sphingosine-1-phosphate and lysophosphatidic acid prevent apoptosis in osteoblastic cells via a signaling pathway involving $\mathrm{G}(\mathrm{i})$ proteins and phosphatidylinositol-3 kinase. Endocrinology 143 4755-4763.

Guan XM, Yu H, Palyha OC, McKee KK, Feighner SD, Sirinathsinghji DJ, Smith RG, Van der Ploeg LH \& Howard AD 1997 Distribution of mRNA encoding the growth hormone secretagogue receptor in brain and peripheral tissues. Molecular Brain Research 48 23-29.

Holst B, Cygankiewicz A, Halkjar Jensen T, Ankersen M \& Schwartz TW 2003 High constitutive signaling of the ghrelin receptor-identification of a potent inverse agonist. Molecular Endocrinology 17 2201-2210.

Howard AD, Feighner SD, Cully DF, Arena JP, Liberator PA, Rosenblum CI, Hamelin M, Hreniuk DL, Palyha OC, Anderson J et al. 1996 A receptor in pituitary and hypothalamus that functions in growth hormone release. Science 273 974-977.
Jansen JH, Weyts FA, Westbroek I, Jahr H, Chiba H, Pols HA, Verhaar JA, van Leeuwen JP \& Weinans H 2004 Stretch-induced phosphorylation of ERK1/2 depends on differentiation stage of osteoblasts. Journal of Cell Biochemistry 93 542-551.

Jeffery PL, Herington AC \& Chopin LK 2003 The potential autocrine/paracrine roles of ghrelin and its receptor in hormonedependent cancer. Cytokine Growth Factor Reviews 14 113-122.

Kim MS, Yoon CY, Jang PG, Park YJ, Shin CS, Park HS, Ryu JW, Pak YK, Park JY, Lee KU et al. 2004 The mitogenic and anti-apoptotic actions of ghrelin in 3T3-L1 adipocytes. Molecular Endocrinology 18 2291-2301.

Kim SW, Her SJ, Park SJ, Kim D, Park KS, Lee HK, Han BH, Kim MS, Shin CS \& Kim SY 2005 Ghrelin stimulates proliferation and differentiation and inhibits apoptosis in osteoblastic MC3T3-E1 cells. Bone 37 359-369.

Kojima M, Hosoda H, Date Y, Nakazato M, Matsuo H \& Kangawa K 1999 Ghrelin is a growth-hormone-releasing acylated peptide from stomach. Nature 402 656-660.

Kojima M \& Kangawa K 2005 Ghrelin: structure and function. Physiological Reviews 85 495-522.

Larsson B, Gritli-Linde A, Norlen P, Lindstrom E, Hakanson R \& Linde A 2001 Extracts of ECL-cell granules/vesicles and of isolated ECL cells from rat oxyntic mucosa evoke a Ca2+ second messenger response in osteoblastic cells. Regulatory Peptides 97 153-161.

Larsson B, Norlen P, Lindstrom E, Zhao D, Hakanson R \& Linde A 2002 Effects of ECL cell extracts and granule/vesicle-enriched fractions from rat oxyntic mucosa on cAMP and IP(3) in rat osteoblast-like cells. Regulatory Peptides 106 13-18.

Maccarinelli G, Sibilia V, Torsello A, Raimondo F, Pitto M, Giustina A, Netti C \& Cocchi D 2005 Ghrelin regulates proliferation and differentiation of osteoblastic cells. Journal of Endocrinology 184 249-256.

Murata M, Okimura Y, Iida K, Matsumoto M, Sowa H, Kaji H, Kojima M, Kangawa K \& Chihara K 2002 Ghrelin modulates the downstream molecules of insulin signaling in hepatoma cells. Journal of Biological Chemistry 277 5667-5674.

Nanzer AM, Khalaf S, Mozid AM, Fowkes RC, Patel MV, Burrin JM, Grossman AB \& Korbonits M 2004 Ghrelin exerts a proliferative effect on a rat pituitary somatotroph cell line via the mitogen-activated protein kinase pathway. European Journal of Endocrinology $151233-240$.

Osyczka AM \& Leboy PS 2005 Bone morphogenetic protein regulation of early osteoblast genes in human marrow stromal cells is mediated by extracellular signal-regulated kinase and phosphatidylinositol 3-kinase signaling. Endocrinology 146 3428-3437.

Papotti M, Ghe C, Cassoni P, Catapano F, Deghenghi R, Ghigo E \& Muccioli G 2000 Growth hormone secretagogue binding sites in peripheral human tissues. Journal of Clinical Endocrinology $\mathcal{E}$ Metabolism 85 3803-3807.

Sibilia V, Cocchi D, Pagani F, Lattuada N, Moro GL, Pecile A, Rubinacci A, Muller EE \& Netti C 1999 Hexarelin, a growth hormone - releasing peptide, counteracts bone loss in gonadectomized male rats. Growth Hormone IGF Research 9 219-227.

Sun Y, Ahmed S \& Smith RG 2003 Deletion of ghrelin impairs neither growth nor appetite. Molecular and Cellular Biology 23 7973-7981.

Sun Y, Wang P, Zheng H \& Smith RG 2004 Ghrelin stimulation of growth hormone release and appetite is mediated through the growth hormone secretagogue receptor. PNAS 101 4679-4684.

Tamura H, Kamegai J, Sugihara H, Kineman RD, Frohman LA \& Wakabayashi I 2000 Glucocorticoids regulate pituitary growth hormone secretagogue receptor gene expression. Journal of Neuroendocrinology 12 481-485.

Thompson NM, Gill DA, Davies R, Loveridge N, Houston PA, Robinson IC \& Wells T 2003 Ghrelin and des-octanoyl ghrelin promote adipogenesis directlyin vivo by a mechanism independent of GHS-R1a. Endocrinology 145 234-242. 
van der Lely AJ, Tschop M, Heiman ML \& Ghigo E 2004 Biological, physiological, pathophysiological, and pharmacological aspects of ghrelin. Endocrine Reviews 25 426-457.

Weyts FA, Bosmans B, Niesing R, Leeuwen JP \& Weinans H 2003 Mechanical control of human osteoblast apoptosis and proliferation in relation to differentiation. Calcified Tissue International $\mathbf{7 2}$ 505-512.

Wortley KE, Anderson KD, Garcia K, Murray JD, Malinova L, Liu R, Moncrieffe M, Thabet K, Cox HJ, Yancopoulos GD et al. 2004
Genetic deletion of ghrelin does not decrease food intake but influences metabolic fuel preference. PNAS $1018227-8232$.

Zhang W, Zhao L, Lin TR, Chai B, Fan Y, Gantz I \& Mulholland MW 2004 Inhibition of adipogenesis by ghrelin. Molecular Biology of Cell 15 2484-2491.

Received 8 September 2005 Accepted 21 September 2005 